\title{
Islam and the Economic Challenge
}

\author{
By M. Umer Chapra. Leicester, UK: The Islamic Foun- \\ dation and IIIT, 1992, $428 \mathrm{pp}$.
}

I consider the task of reviewing this book an honor as well as a challenge. My task is made even more difficult and the challenge more significant when I read excellent reviews from both intellectual spectra, Western as well as Islamic. From the West, Kenneth Boulding, an eminent behavioral scientist and social economist, expresses his admiration both for the author's readable style as well as the depth and the maturity of his knowledge when he writes:

This is an excellent work. . . His understanding is quite sophisticated. At the same time his style is clear and he writes with humanity and a very deep concern for the welfare of the human race.

From the East, the book has already received and incorporated comments and suggestions from a number of economists at the forefront of research in Islamic economics, among them Dr. Nejatullah Siddiqui and Professor Khurshid Ahmad. The latter economist has very succinctly summarized not only his own views but also those of other Islamic scholars when, in the foreword, he writes:

Dr. Chapra has dealt with the subject as a trained social scientist and objective Islamic scholar. His grasp of the contemporary systems and their problems is thorough and incisive, his presentation of Islamic economic order is concise and convincing. His balanced critique of the western systems as well as that of the contemporary Islamic society is presented in a style that is scholarly yet simple, clear and prescriptive. . . . Dr. Chapra has clearly demonstrated that well being can not be attained through the pursuit of material possessions alone and that efficiency and equity can become operational concepts only if they are redefined in the context of their linkage to moral values and socioeconomic structures." 
These reviews provide the reader with an appreciation of the task in front of me. As a result, I have decided to limit my review to a broad overview of the entire book. I will attempt to highlight only the most noteworthy general thesis and will avoid technical economic jargon as much as possible. The views expressed are my own.

The book is a thoroughly researched and fully integrated collection of topics. Each chapter covers a specific economic issue: The Limits of Capitalism; The Retreat of Socialism; The Crisis of the Welfare State; The Inconsistency of Development Economics; The Islamic World View and Strategy; The Malaise; Invigorating the Human Factor; Reducing the Concentration of Wealth; Economic Restructuring; Financial Restructuring; and Strategic Policy Planning. Since each chapter can be viewed as an independent subject, I decided to focus on the author's main thesis and have confined myself to a discussion and critical evaluation of the book's broader theme and the recommended policy measures.

His book focuses on presenting the economic problems, evaluating the economic systems designed to solve them (i.e., capitalism, welfare state, socialism, and communism); conducting a critique of these systems; explaining the Islamic perspective; and finally suggesting specific prescriptive policy measures consistent with the Islamic worldview.

According to economists, all economic activities revolve around three basic societal problems: what to produce, how to produce, and for whom to produce. The first question relates to the quantity and type of goods and services that a society prefers to consume. The second is concerned with the industrial organization and technology that a society could and should use to establish and operate its production methods, processes, and organizational structure. The third question deals primarily with the ways and means of distributing the total production among a society's various groups and individuals.

Economists recognize that these problems are created by a scarcity of material resources and the unlimited claims on them. In order to improve and increase the availability and equitable distribution of resources, a society must introduce efficiency in its production of goods and follow the principal of equity in their distribution. Thus the achievement of efficiency and equity could be viewed as common goals for every economic system. While all economic systems devised by humanity claim that they are working to achieve these goals, none of them so far has even partially succeeded.

After describing the economic problem, Chapra critiques the various economic systems. Capitalism, although very successful in energizing human resources and invigorating the entrepreneurial motives to provide efficiency, has failed because it has not adequately addressed the problem 
of equity. Economic history provides sufficient testimony to the fact that economic activity, when left entirely to the exercise of self-interest as a motivating force and without any guidance from moral and societal values, leads to the exploitation of weaker groups. The unrestrained exercise of the profit motive has led to widespread victimization of women, children, and other groups with little or no bargaining power.

As a result of these and other internal inconsistencies and contradictions, capitalism gave way to the welfare and mixed economic system. This system tried to create a balance between the demands of labor for decent wages and the desire of capitalist entrepreneurs for a reasonable profit margin. This fine-tuning and balancing act has become a permanent feature of the mixed economies of the United States, Europe, and Japan. Unfortunately, even those countries that were very successful in fulfilling the goals of efficiency through the application of high technology in the production and organization processes have yet to solve the problem of fluctuating employment levels, economic cycles, and an equitable distribution of goods.

Socialism and communism started out to correct both the exploitative nature of laissez faire capitalism, resource misallocation, and the inequitable distribution characteristic of modern mixed economies. Despite its concerted effort during the last four decades, these systems, although successful in being more equitable in the distribution of resources, have failed miserably in their overall performance as economic as well as sociopolitical systems. The elimination of the individual's entrepreneurial spirit and vitality removed all incentives for growth and development and destroyed the system from within.

In his discussion of the rise and fall of these systems, Chapra goes far beyond the narrow confines of technical economics and displays a keen and true insight as a social reformer and humanist. His exposition and economic analysis of these systems are clear, his understanding is deep, and his conclusions about their failures, although spirited and slightly exaggerated, are sufficiently supported by historical facts as well as empirical research.

Having analyzed the failures of these systems, Chapra discusses how Islam resolves the conflict between the achievement of efficiency and equity. Islam accomplishes this in two ways. First, it redefines the goal of economic activity by expanding it from the narrow and purely materialistic satisfaction of human demands to one that provides both material as well as spiritual well-being. Since well-being includes both the consumption of private as well as the provision of public goods, this comprehensive definition justifies an active role for the government. According to this definition, the government's role is to create and promote an envi- 
ronment for the fulfillment of both individual and social needs.

It should be noted here that all economic systems, from the extreme of pure capitalism to that of communism, have addressed spirituality and equity differently. All Western economic systems treat spirituality and the various religious codes of ethics and beliefs as pursuits left for individuals and families to follow on their own. The issue of equity has also been treated differently by Western systems. Capitalism, in its pure form, has left it completely untouched, whereas the economic philosophies of the welfare state, socialism, and communism have considered this problem with various degrees of concern and have included it as an issue for the state's public policy and economic objectives.

The Islamic model defines human welfare as including both material progress and spiritual enhancement. In order to achieve societal wellbeing, Islam places equal emphasis on efficiency in the use of economic resources as well as an equitable distribution of these resources. To enhance spirituality, Islam rejects the Western concept of separation of church and state. It advocates a comprehensive and coherent political system where the state, instead of being a neutral observer in matters of religion and private piety, becomes an active participant and promoter of moral and spiritual values. In this system, activities considered immoral, unethical, socially undesirable, unhealthy, indecent, and dishonest in social life and unfair and noncompetitive in business affairs are not left to be controlled and condemned by individual churches and social groups. These are declared illegal by the state and their spread, promotion, and practice are stopped by the rigorous application of the state's legal power and constitutional authority. In this system, the state acts as a promoter and protector of individual rights and liberties. It also uses its policy instruments and moral and legal authority to create an environment that encourages family values, wholesome living, and the establishment of a legal, social, political, and economic environment conducive to the fulfillment of material as well as spiritual well-being of its citizens.

Is there any Muslim country in the world where such an environment exists? Chapra correctly answers this question with an emphatic "no." While conducting a critical evaluation of the current state of affairs in the Muslim countries, he forcefully points out that they are an embarrassment for Muslims at large. They represent a dark picture of social, political, and economic failure to all. Most of them are so miserably poor that they fail to provide even the most basic necessities of life to their citizens. Their development plans are characterized by reliance on heavy industries financed by foreign debt and charity. They either borrow money or beg for it. The concentration of wealth and economic power in a few individual hands and families is the norm for these countries. They are go- 
verned by self-appointed despotic rulers who have perpetuated nondemocratic political systems in order to ensure the continuation of their power. Their administrative structure is full of inept bureaucratic functionaries who are unfair, unresponsive, and repressive. The entire system is reeling with widespread corruption and nepotism.

Reforming such a system is a herculean task. In this environment, even the most modest economic policies are doomed to failure because they weaken the power of the national, state, or local politicians as well as that of local ethnic, religious groups, the privileged, or the powerful. In the context of this deplorable state of affairs, one can ask two questions: a) how could a country and its people break away from these shackles and free themselves from these repressive and unjust systems; and b) once free, what are the specific socioeconomic policies that can fulfill the twin objectives of material well-being and spiritual advancement simultaneously?

Let us look at the first question. It is an undeniable historical fact that appropriate social, political, and legal changes in a society are a prerequisite to the implementation of any economic policy. One cannot promote enterprise or business development without legalizing private ownership of the means of production, nor can a society promote world trade without establishing a legal and political system that protects a trader's right to repatriate profit. Even in a communist system, one cannot maintain the production of a certain amount and quality of specific goods exclusively within the guidelines of the state plan unless one prohibits the production and import of similar goods by those not accepted by the state.

All economic relationships draw their support, sustenance, and growth from the state, the social customs, and the legal and political framework that exist within a society. Therefore the implementation of reforms in Muslim countries would require a fundamental structural change in the political and social arenas. As the current economic, social, political, and legal structures have assumed a degree of permanence in, even minor reforms, whether internal or external, have very little chance of success. Furthermore, in this age of mass communication, no new movement, policy, or action is going to receive the people's full support unless they are convinced of its validity and effectiveness as well as the government's and its representatives truth, honesty, sincerity, and character.

A democratic form of government which is fairly and honestly elected by the majority is the only means that can provide an effective mechanism for bringing about a consensus on policy goals. However, the problem with most Muslim countries is that they are not governed by legitimate and democratically elected governments. Most are either ruled by hierarchical rulers, agents of foreign powers, or those who have no 
commitment to either Islamic or any other ideology. They rule through political expediency and the desire to promote and preserve their own narrow tribal, ethnic, or regional interests. More recently, Iran and Algeria provided a ray of hope. Unfortunately they are under continuous threat. Iran has long been a target of foreign intrigues, while Algeria's emerging Islamic democracy is being threatened from within by its own Westernoriented military and bureaucratic elite.

In his discussion of the malaise presently afflicting the Muslim world, Chapra recognizes this situation and strongly recommends the establishment of democratic governments in Muslim countries. However, he fails to propose any specific policies, measures, or actions which the Muslim masses could use to achieve this objective. He could have mentioned the fact that hereditary rulers and despotic regimes have not always handed power over to the people in a peaceful manner. They have often been forcibly removed from power through a mass movement or internal revolution. Such revolutions will always find support in the Islamic worldview so long as they establish justice and remove tyranny.

Assuming that a democratic government has been established, one then needs to address the second question: what specific economic policies could be designed to achieve economic well-being within the context of Islamic ideology? Chapra provides a comprehensive discussion of specific policy measures in the last five chapters. His discussion of the Islamic worldview, the major theme of his recommended policy measures, and the economic analysis and justification for these policies are all written with the expertise of a professional economist who is sensitive to the depressing realities of life for the Muslim masses. The main thesis and primary underlying idea behind these policies is his belief that, unlike the prevailing Western economic systems, the Islamic perspective considers equity and Islamic justice and fairness to be the core of its strategy. This concern for equity is so overriding that if an Islamic society has to choose between the two, equity takes precedence over efficiency.

Recognizing the competitive nature of equity and efficiency, Chapra proposes a development strategy that focuses on increasing the level of production and reducing claims on this production. When implemented, his strategy will result in an increased production of what economists call the basic necessities - food, clothing, and shelter-and a curtailment of the production of frivolous luxury goods associated with conspicuous consumption. This limitation is essential, for the production of luxury goods requires an inordinate amount of resources and only helps to fulfill the demands of a small minority. A logical consequence of this shift in emphasis to the prioritization of public policy to promote goods for mass consumption and their equitable distribution is Chapra's subsequent rec- 
ommendation that micro-, small-, and medium-sized business enterprises (SMEs) be developed and promoted through the redirection of fiscal and monetary policies. These and other specific economic and policy measures (i.e., invigorating the human factor; motivating individuals; reducing the concentration of wealth; prioritizing individual and public spending and taxes; financial restructuring to emphasize small-, micro-, and medium-sized businesses; and strategic policy planning designed to overhaul the administrative, educational, and political systems) are all discussed in the last five chapters.

As pointed out earlier, Chapra views these policy measures as a comprehensive prescription to correct both economic imbalance as well as the social, political, and legal injustices that currently pervade the Muslim world. However, when these policies are critically evaluated within the framework of an analytical economic perspective and a recognition of social and economic reality, their realization would in my view be limited by the following considerations.

First, it is extremely difficult to imagine how the current situation in these countries could allow the implementation of even a few of these policies. While Chapra recognizes this limitation, he refrains from advocating any specific measures for the democratization of these countries beyond stating that a democratic and representative political system is needed for the full and effective implementation of these policies.

Second, while he strongly endorses and promotes the spread of SMEs in the Muslim world, he appears to be overly concerned with the prevalence of the inequitable distribution of wealth and other short-term economic maladies currently afflicting these countries. Before taking a strong stand for SMEs, he should have provided a detailed discussion of the trade-off between efficiency and equity. His policy recommendations imply a significant bias towards the short-term at the expense of long-term economic efficiency and growth and a balanced national development.

Thirdly, in advocating a simultaneous implementation of these policies, Chapra seems to have ignored the fact that some of these policies, if implemented without prioritization, may lead to mutually exclusive economic outcomes. Since the last two points are directly based on economic analysis, I will elaborate on these two points.

Chapra recommends the SME strategy primarily due to its effectiveness in fulfilling Islamic objectives. There is no question that his proposed model of economic growth, which is based on the establishment and encouragement of SMEs, is not only economically viable in the shot term but thai it is also more likely to make significant contributions to the long-term goal of achieving the equitable distribution of wealth. Its full impact on a country's long-term economic growth and competitiveness 
is, however, debatable. He fails to engage in a broader discussion of this issue, and therefore does not consider the possibility that the realization of the short-term goal of equity and the provision of a minimum standard of living to the great majority is not necessarily compatible with the fulfillment of Islamic objectives. Furthermore, the constraints of limited resources will always necessitate a trade-off between short-term objectives and long-term economic goals.

As for the impact of SMEs on the long-term development of Muslim countries, the adoption of such a policy will result in long-term dependency on external nations, organizations, and individuals. If they were to fully devote their economic resources to the development of SMEs "by discouraging large enterprises except where they are inevitable," even under the assumption of complete world peace, these countries would remain unable to produce a great number of essential industrial products (i.e., computers, aircraft, shipping, heavy chemicals, industrial and construction equipment and materials, and a host of other products), for the simple economic fact that only large-scale enterprises can achieve the economies of scale needed to produce these products efficiently and at the lowest possible cost.

It should also be recognized that economic development through the encouragement of SMEs is only one of many growth models compatible with an Islamic framework. At this point, I would like to propose an alternative model which, although not original, can provide an alternative route towards the fulfillment of both short-term objectives and long-term goals: a European Economic Community (EEC) model that emphasizes the Islamic principle of equity and fairness in the distribution of natural, human, and capital resources. The EEC model would require a restructuring of Muslim countries to achieve the efficient allocation of natural resources within their boundaries, and the spirit of Islam would ensure an equitable distribution of production among the participants. In the political arena, the new structure would require a modification of the borrowed Western concepts of national sovereignty and the nation-state that currently provide legitimacy to these Muslim countries.

The implementation of this model requires many elements: the establishment of a Muslim parliament; the promotion of democracy with free and impartial elections; the renunciation of claims on each other's territory; common citizenship rights, defense, and foreign policy; the decentralization of local administration; and the establishment of small autonomous internal and/or external ethnic enclaves. In economic relations, this model would require free trade and the free movement of labor and other economic resources among Muslim countries. In monetary affairs, they would need to establish either a common currency, or fully convertible 
currencies, and a centrally controlled and disciplined monetary agency to coordinate the money supply and currency floats.

Such economic cooperation would help to create an environment in which industries, agricultural enterprises, transportation systems, and commercial and trading houses of all sizes and scales could flourish side by side. Both the enterprises' scale and location would be determined purely on the grounds of economic efficiency and productivity as dictated by the economic principle of comparative advantage. In this environment, the fruits of increased economic productivity and efficiency would be shared by all participants on the basis of their contribution to the total productivity. In this economy, those unable to contribute would be provided with a minimum liveable allowance through zakah and charity funds that could be managed by autonomous state-supported or privately administered agencies.

This model's successful implementation and operation naturally assumes its acceptance by the resource-rich Muslim countries. It also requires a political framework for the establishment of a political entity with the necessary authority and force to implement its decisions. These countries will need to accept limitations to their sovereignty and the implementation of Islamic principles in economic as well as all other spheres. In order to achieve this, young Muslim revolutionaries will have to undertake to change the existing political status quo. Young Muslim economists will have to initiate economic research designed specifically to explore and validate the benefits of economic cooperation and coordination of development strategies among Muslim countries.

My third concern, as mentioned above, is the existence of contradictory outcomes if some specific policy measures recommended by Chapra are implemented simultaneously. These policies include breaking up existing concentrations of wealth, reinvigorating the entrepreneurial drive, and controlling the flight of capital. Let us see how these contradictory outcomes could occur with the simultaneous implementation of specific policies designed to achieve these objectives.

In their attempt to design specific economic policies to remove or reduce the concentration of wealth, Islamic policymakers will have to resolve the problem of defining the term "concentration." They will then have to find justification and consensus from Islamic literature to establish an Islamically acceptable level of wealth that an individual or family can acquire. At present, there does not seem to be any well defined and empirically justifiable criteria, or a consensus based on specific guidelines from Islamic literature, by which this level can be ascertained. For the sake of argument, suppose that an entrepreneur has accumulated his/her wealth, within the framework of the Islamic 
principles of inher-itance, by following fair and honest business practices and regular pay-ment of all financial obligations (i.e., zakah and other taxes). Who, then, is to say that his net worth cannot exceed one million, one billion, or any other dollar amount?

On the other hand, suppose that a threshold is empirically discovered and is agreed to by Islamic legislators and scholars. One could then ask if the same threshold would apply to all economic sectors-agriculture, industry, and commerce-or would one have to define different levels for different economic sectors and endeavors? This is what the economic principle of efficiency would demand, but it is also what the principle of equity would reject.

Furthermore, once such a threshold for a permissible level of wealth is established, economic policies of taxation, appropriation with compensation, or nationalization would have to be applied to maintain this arbitrarily defined level of wealth concentration. If these policies were implemented, policymakers would face another problem that will have a negative impact on those policies designed to promote entrepreneurship and control the flight of capital. Economic theory and empirical research provide undisputed evidence that when cconomic policymakers tinker with setting arbitrary limits on the accumulation of wealth, they severely injure the spirit of entrepreneurship. At the same time, such a policy significantly accelerates the flight of capital outside the country. No country has ever developed without entrepreneurs, and no entrepreneur has ever invested his/her best effort in a business without proper incentives. The unending migration of professionals and the uncontrollable flight of capital from the developing to the developed world are not unusual or exceptional phenomena; they are primarily the results of similar ill-conceived economic policies.

To conclude, let us hope that this review stimulates further discussion of various economic issues within an Islamic perspective.

Imtiaz Uddin Ahmad University of Maryland, Eastern Shore Princess Anne, Maryland 